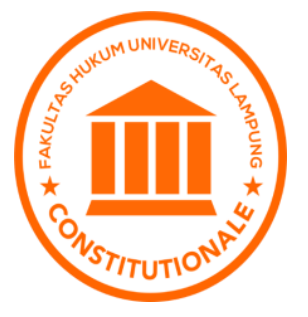

\title{
CONSTITUTIONALE
}

Volume 2 Issue 1, January-June 2021: PP: 57-68

Faculty of Law, Universitas Lampung, Bandar Lampung,

Indonesia.

http://jurnal.fh.unila.ac.id/index.php/constitutionale

P-ISSN: 2723-2492 E-ISSN: 2745-9322

\section{The Romanian Superior Council of Magistracy's Role in the Protection of The Law Enforcement}

\author{
Dragoș Călin \\ dragos.calin@just.co \\ Bucharest Court of Appeals, Romania
}

Submitted: 14 January 2021; Reviewed: 19 March 2021; Accepted: 4 April 2021

\begin{tabular}{lll}
\hline \multicolumn{2}{c}{ Article's Information } & \multicolumn{1}{c}{ Abstract } \\
\hline $\begin{array}{l}\text { Keywords: } \\
\text { Council. }\end{array}$ Reputation; Judiciary; System; & $\begin{array}{l}\text { The Romanian Superior Council of } \\
\text { Magistracy (RSCM) has failed to } \\
\text { provide stability as an active form of } \\
\text { involvement to defend the judicial } \\
\text { https://doi.org/10.25041/constitutionale.v2i1.2253 } \\
\text { officers against acts that injures their } \\
\text { independenc, impartiality, and } \\
\text { professional reputation. The } \\
\text { disrespect towards the juidical } \\
\text { officers through the media have not } \\
\text { motivated the RSM to take any } \\
\text { actions. This is not aligned with their } \\
\text { responsibility to clarify any miss- } \\
\text { leading information. The RSCM has } \\
\text { yet to overcome the flawed integrity } \\
\text { of the judiciary system. }\end{array}$ \\
\hline
\end{tabular}

\section{A. Introduction}

According to article 133 paragraph (1) of the Romanian Constitution, the Superior Council of Magistracy (RSCM) is obligated to defend the wellness the judicial officer's prosperity. The Superior Council of Magistrcy (RSCM) has the duty to take all necessary measures to defend judicial officers (judges and prosecutors) against any act that will impact their independenc, impartiality, or professional reputation. The RSCM's role is aligned with Article 133 Paragraph (1). According to Article 30 of Law No/2004 regarding the Superior Council of Magistracy and Law No. 234/2018 through subsequent amendment that the RSCM has the authority and obligation to give protection towards the court's body which includes judges and prosecutors. This protection supposedly will provide support for the court's integrity. 


\section{B. Discussion}

\section{The role of the Romanian Superior Council of Magistracy to defend the body of judges and prosecutors against acts that affect theirindependence, impartiality or professional reputation}

The competencies of RSCM Plenum in defence of the professional reputation of judges are restricted in Law No. 234/2018. The only form that can be achieved between judges and prosecutor in strict division, without the risk of amendments declared unconstitutional. The consistency of political law has been a center attention for a long period in the history of political thoughts. ${ }^{1}$ Therefore, altering the basic law is not the appropriate ways to intervent the role and attribution of the RSCM that is established by the consistution, respectively for its sections as structures on the field of disclipinary liability. The Basic law must be in accordance with the law anapply its regulated authority in a respective manner. ${ }^{2}$ Roles and responsibilities between the RSCM Pleum and the RSCM Sections deviate the constitutional role of RSCM by passing the constitutional attributions specific to the sections. This is not aligned with Article 125 Paragraph (2), Article 133 Paragraph (1), and Article 134 Paragraph (2), and (4) of the Constitution. ${ }^{3}$ Article 125 is in the court section, whereas Article 133-134 is in the superior council of magistracy section. ${ }^{4}$

In attempts to comprehend the constitutional competencies of the Superior Council of Magistracy's, we are required to study provisions of Article 133 Paragraph (2) letter (a) and Article 134 Paragraph (2) of the Constitution. The strengthened anaylisis between two constitutional texts describes the facts that the two sections of Magistracy of the Superior Council does not only consist of all members of the RSCM. The only 14 elected members in the general assemblies of judicial officers and validated by the senate. These 14 member consist of 9 part of the section for judges and 5 prosecutors are section parts for prosecutors. Article 134 paragraph (2) of the Romanian Constitution regulates the constitutional role. According to the Superior Councile of Magitstracy, the provision fulfils the role of a court in disciplinary liability for judicial officers through its sections which is aligned with the procedure established by its organic law including the integrity assessment of judges. ${ }^{5}$

Based on this fact, it is infer that the constituent law maker unambiguously created the role of sections of the Superior Council Magistracy. This establishment exclusively engulf the disciplinary liability field, specifically for judicial officers, which is a particular element of the Superior Council of Magistracy's general role. As a whole, the judicial officer is a guardian of the judiciary's independence. It is underlined that both impartiality and

\footnotetext{
${ }^{1}$ Benjamin Straumann, "Roman Ideas on the Loose," Critical Analysis of Law 4, no. 2 (November 30, 2017), https://cal.library.utoronto.ca/index.php/cal/article/view/28856.

${ }^{2}$ Razvan Viorescu, "CONFLICTS OF A CONSTITUTIONAL NATURE BETWEEN THE GOVERNMENT OF ROMANIA AND THE JUDICIAL AUTHORITY - THE SUPERIOR COUNCIL OF MAGISTRACY," European Journal of Law and Public Administration 3, no. 2 (2016): 5-17.

${ }^{3}$ See the viewpoints drafted by the Romanian Judges' Forum Association, available at web page web http://www.forumuljudecatorilor.ro/wp-content/uploads/FJR-Aspecte-privind-prevederi-din-legile-justitieineconforme-Constitutiei-sau-tratatelor-internationale.pdf[last consulted at 08.02.2020].

${ }^{4}$ Pavel Nicolae, "SELECTIVE ASPECTS ON THE EVOLUTION OF THE REGULATIONS REGARDING THE JUDICIARY IN THE ROMANIAN CONSTITUTIONS AND IN THE ROMANIAN LAW 100 YEARS AFTER THE GREAT UNION," Revue Européenne Du Droit Social, no. 04 (41) (2018): 22-38.

5 Natalia Creciun, "Particular Forms of Evaluation and Assessment of Judges: Between Exigency of a Consolidated Justice and Violation of Justice Independence," Revista Institutului National Al Justitiei 49 (2019), https://heinonline.org/HOL/Page?handle=hein.journals/rvisnjut49\&id=55\&div=\&collection=.
} 
independence could not be taken for granted. ${ }^{6}$ Thus, it has become a main reason for the constitutional law maker to refer to the Plenum of the Superior Council of Magistracy when the Superior Council of Magistracy is used. The Plenum of the Superior Council of Magistracy regulates the liability disciplinary of judicial offers (judges and prosecutors). Regarding this, the law makers's expressis verbi refers to the secions of Superior Council of Magistracy.

In this respect, the competenceunder the RSCM's sections represents a firm position to protect the judiciary's interest. Moreover, it covers that the judges and prosecutors are implemented without an external exposure, especially by their representative electors. Subsequently it is inadmissible to transition towards organic law, since the Romanian Constititution regulates general competence for the Superior Council of Magistracy's plenum as an assortment. If the opposed were true, it means that in theory, one could create two de facto structures of the Superior Council of Magistracy. These structures are for judges and prosecutors. On another hand, this legislative solution defines the constitutional role established by the constituent lawmaker for the Superior Council of Magistracy as a single constitutional authority representative for judicial officers. However, it would lead to significant accentuation of the section's corporatism. This accentuation would not only affect the independence of justice, but also the constitutional principle of cooperation within the judicial authorities.

The judicial court acknowledges impartiality as one of their principles. These principle allows the court to have impartiality and professional integrity in their implementation. ${ }^{7}$ According to this principle, decisions that affects f judicial's authorities shall be taken in the plenum, except those in disciplinary matters. Independence in the judiciary system is the ability of judges to decidw without internvention. ${ }^{8}$ The decision is performed with the participation of the judicial officers' representatives. The institution significant representative attributions in respect to the judicial authority includes the President of the High Court of the Cassation and Justice, the general prosecutor of the prosecutor's office attached to the High Court of Cassation and Justice, the minister of justice, and representative of civil society. ${ }^{9}$ In other constitutional system, distinct legal councils were created by the fundamental law, especially in condition where the constituent law mekae intended to mark a distinction between professional bodies of judges and prosecutors.

Opinion No. 10 (2007) of the Consultative Council of European Judges (CCJE) to the Committee of Ministers of the Council of Europe on the Council of Justice at the service of society covers on the justice image's protection. Through opinion no. 7 (2005), the CCJE suggests the member states to:

a. Partake in programs that targets in public socialization regarding the justice system.

b. Convince an independent body that specializes in judicial presses representation

c. If a judge is involved in a misleading press, this particular judge are recommended to not give any spontaneous reaction.

\footnotetext{
${ }^{6}$ Alex Schwartz and Melanie Janelle Murchison, "Judicial Impartiality and Independence in Divided Societies: An Empirical Analysis of the Constitutional Court of Bosnia-Herzegovina," Law \& Society Review 50, no. 4 (December 1, 2016): 821-55, https://doi.org/10.1111/lasr.12237.

${ }^{7}$ Bianca Selejan-Guțan, "Romania: Perils of a 'Perfect Euro-Model' of Judicial Council," German Law Journal 19, no. 7 (December 1, 2018): 1707-40, https://doi.org/10.1017/s207183220002321x.

8 Helen Keller and Severin Meier, "Symposium on Jeffrey 1. Dunoff and Mark a. Pollack, 'the Judicial Trilemma' Independence and Impartiality in the Judicial Trilemma," in AJIL Unbound, vol. 111 (Cambridge University Press, 2017), 344-48, https://doi.org/10.1017/aju.2017.85.

${ }^{9}$ Piotr Mikuli, "In Search of the Optimal Court Administration Model for New Democracies," in Judicial Power in a Globalized World (Springer International Publishing, 2019), 281-89, https://doi.org/10.1007/978-3-03020744-1_18.
} 
d. The urgency of finding balance between rights and freedom is the main concern of the Council of Justice.

2. Defence of the independence, impartiality or professional reputation of judges and prosecutors by the Romanian Superior Council of Magistracy between 2017 and April 2019.

Under the cooperation and verification mechanism on 2017, the commission report by the RSCM to the European Parliament suggested the RSCM take full responsibility to the judiciary system. Moreover, professionalism categorizes the legal occupation as a specific profession. ${ }^{10}$ There were 19 application made in regards of reputation, independence, and impartiality.

1) In 2017, the RSCM proposed 10 application for professional reputation defence for the interest of individual judicial officers in regard to the judiciary system's independence.

2) In 2018, the RSCM proposed 10 application of professional reputation defence of judicial officers and system's independence.

3) In 2019, the RSCM proposed 8 application of professional reputation's protection towards the judicial officers and independence.

4) Due to this situation, the RSCM has regressed in adopting their decisions compared to their performance in 2014-2016 which is $25 \%: 75 \%$.

\section{APPLICATIONS ADMITTED BY THE PLENUM OR THE SCM SECTIONS}

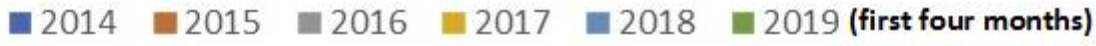

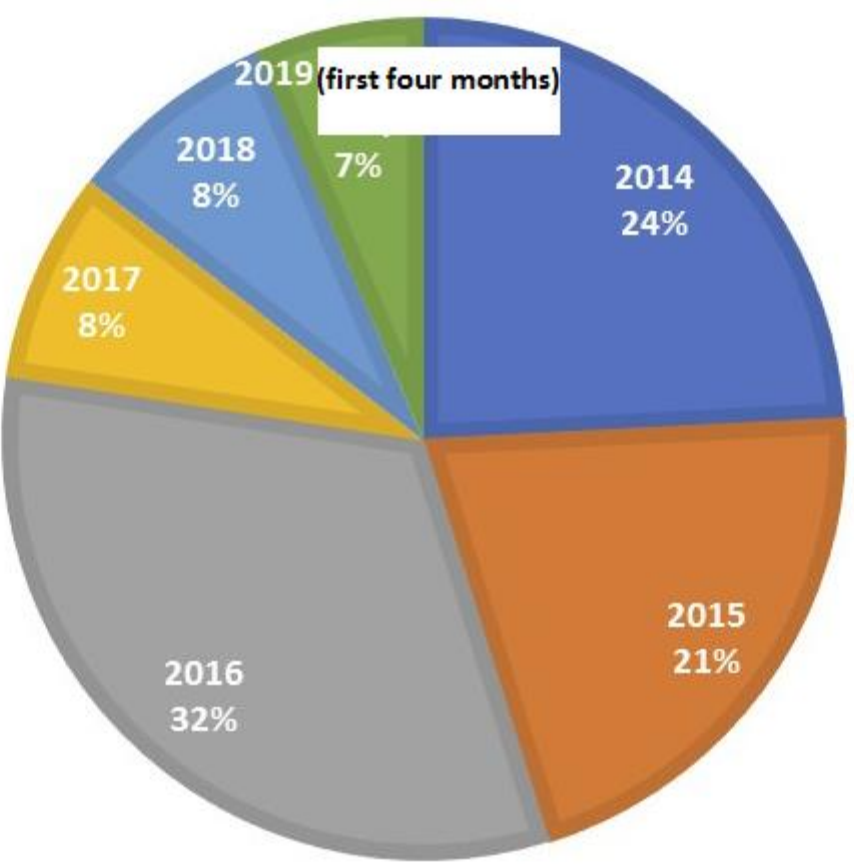

There are three consideration considering there requests which are:

\footnotetext{
${ }^{10}$ Nina L. Holvast and Nienke Doornbos, “Exit, Voice, and Loyalty within the Judiciary: Judges' Response to New Managerialism in the Netherlands," Utrecht Law Review 11 (2015), https://heinonline.org/HOL/Page?handle=hein.journals/utrecht11\&id=147\&div=\&collection=.
} 
1) Regarding the duration of proceedings of these requests, the average of two months from registration, which existed between 2015 and 2016, it was frequently exceeded in the period 2017-2019.

2) Regarding the time limit for publishing the reasons for the rulings handed downin the matter, the 30 days were generally respected, but there were also notable exceptions, without any plausible explanation for delays

3) Regarding the number of votes cast by RSCM members, 9 rulings of theRSCM

3. Qualitative analysis of the requests for defence of the independence, impartiality or professional reputation of judges and prosecutors by the Romanian Superior Council of Magistracy

During all this time, the judiciary system has been subjected to attacksnot met by politicians, whether defendants or not, via channelsmedia controlled by them. The report on the state of justice for 2018, published in May 2019 by the Superior Council of Magistracy, notes as vulnerability"intensifying the attacks launched by politicians and the media at the address of the judges". ${ }^{11}$ Indeed, the Venice Commission found that "there are reports of pressure and intimidation of judges and prosecutors, including some senior politicians and media campaigns," 12 and the Commission's Progress Report on Romania's MCV of 13 November 2018 explicitly mentioned that "judges and prosecutors continued to face attacks on a person in the mass-media, not having sufficient countermeasures". ${ }^{13}$ By the Opinion of the Bureau of the Consultative Council of European Judges of April 25, 2019, issued at the request of the Romanian Judges' Forum Association regarding the situation of the independence of the judiciary system in Romania, the repeated and unprecedented attacks of political actors against judges in Romania ("any comments, comments or remarks in Romania that go beyond the limits of legitimate criticism and seek to attack, intimidate or otherwise pressure judges, or demonstrate disrespect for them, using simplistic, irresponsible or demagogic arguments, or denigrating others way legal system or judges as individuals"). CCJE stressed that "powersexecutive and legislative (...) must give all the necessary and appropriate protection at that timewhen court functions are threatened by attacks or intimidations directed atmembers of the judiciary system. The unbalanced critical commentary of politicians isirresponsible and causes a serious problem because public confidence in the systemjudiciary system can be undermined involuntarily or deliberately. In such cases, the judiciary system must point out that such behavior is an attack on the constitutional order of a democratic state, as well as an attack on the legitimacy of another state power. Such behavior also violates international standards". ${ }^{14}$

Referring strictly to the RSCM's work on the defence of the independence, impartiality or professional reputation of judges and prosecutors, the Report of the Commission to the European Parliament and the Council on the progress made by Romania under the Cooperation and Verification Mechanism of 13 November 2018 and the related Technical Report noted the following:

\footnotetext{
${ }^{11}$ Available at http://old.csm1909.ro/csm/linkuri/06_05_2019_94958_ro.pdf[last consulted on 08.02.2020].

${ }^{12}$ See the Venice Commission Opinion on Amendments to Law no. 303/2004 on the status of judges and prosecutors, Law no. 304/2004 on judicial organization and Law no. 317/2004 on Superior Council of Magistracy, CDL-AD (2018)017, paragraphs 15 and 157.

${ }^{13}$ See the Commission's Report to the European Parliament and the Council on Progress in Romania under the Cooperation and Verification Mechanism (Strasbourg, 13.11.2018 COM (2018)851 final), Section 2 (General), p. 2

${ }^{14}$ See also CCJE Opinion no. 18 (2015) on the position of the judiciary system and its relationship with other state powers in a modern democracy, paragraph 52.
} 
"The Superior Council of Magistracy has not been able to act as a factoreffective control and balance to defend the independence of the judicial institutions under pressure, an important constitutional role highlighted in the January 2017 report. The divisions of the Superior Council of Judicial officers (...) have made it increasingly difficult for the Superior Council of Magistracy to be effective as a bullhorn of the judiciary system - especially when consulted on legislation - and as the administrator of the judiciary system. Even when the Superior Council of Magistracy presented a unanimous opinion, it was ignored in important cases. Although in 2018 judicial institutions and some judges and prosecutors have been the subject of particularly tough public criticism from Government and

Parliament representatives, the Council has been reluctant to take ex officio decisions in response to attacks on the independence of the judiciary system. This entails the risk that the judicial officers will be discouraged from fulfilling their role as a state entity in expressing opinions on issues relevant to the judiciary system. (...) For example, following statements by the Prime Minister, the President of the Senate and the President of the Chamber of Deputies, on the occasion of a rally against the abuses of the justice system dated June 9, 2018, the RSCM Plenum adopted a decision only after a complaint from the Romanian Judges' Forum Association. ${ }^{15}$ Since November 2017, the RSCM has adopted fourrulings in defence of the independence of the judiciary system and four rulings in defenceprofessional reputation, independence and impartiality of judicial officers. From a total of 34 rulings, 6 requests to defend the independence of the judiciary system were rejected and 20 requests for defence of professional reputation, independence and impartiality of judicial officers were rejected." The point of view of the European Commission is not at all decalibrated or unmotivated, on the contrary. Between 2017 and 2019, the ex officio notifications were sublime but lackedalmost completely, although several members of the current RSCM were promising onean active role in defending the body of judicial officers against acts of nature to bringtheir independence, impartiality or professional reputation. ${ }^{16}$

The Prosecutor's Section has automatically filed an application for the case The Plenum's Decision no. 1139/31.10.2017, in which the reputation was defended professional prosecutor Elena Rădescu, a judicial inspector at the Judicial Inspection, in connection with the unrealistic assertions made during the "Sinteza zilei" (Antena 3) broadcasts of 05.09.2017 and 06.09.2017 regarding the activity of the prosecutor in respect of him Lele Alexandru Florian, a former prosecutor. It has been noted that misinformation has occurred in the television show, which is the result of the lack of minimum checks on the subject under discussion. The president of the Superior Council of Magistracy (Mariana Ghena) doubledthe request of the National Anticorruption Directorate which led to the adoption of thePlenum Decision no.500/25.04.2017, which found to affect the prestige andindependence of the judiciary system in relation to the statements of deputy Sebastian Ghiţă from the shows on Romania TV (28.12.2016-05.01.2017, 13.01.2017, 16.01.2017):

"NAD isthe instrument used by top celebrities and foreign interests to crush the vote of theRomanians. (...) When there is interest in someone in Romania,once benevolent denunciators who know, lie, interpret things in a certain way,favorable to the prosecutor. (...)Thousands, maybe hundreds of thousands of Romanians, began to suffer and tobe dragged into trials and in untrue cases, made on false evidence and not reflectingthe reality. (...) At the request of Mrs. Kovesi, a construction company in Ploieşti,received money from

\footnotetext{
15 Andrew Arato, "Unconstitutional Constitutional Amendments: Constitutional Courts as Guardians of the Constitution?," Constellations 18, no. 3 (September 2011): 324-51, https://doi.org/10.1111/j.14678675.2011.00641.x.

${ }^{16}$ For example, from all existing public data, it does not appear that SCM member Nicoleta Ţînţ has ever proposed to have the Superior Council of Judicial officers refer at least to the Judicial Section.
} 
Asesoft, was the one who paid the plane to bring Mr Nicolae Popa, former director of the FNI, in Indonesia. The reality is that a private company atthe request of the Romanian state and Mrs. Kovesi, paid 200,000 euros to bring the one who went bankrupt to the FNI. (...)Coldea's power over colleagues and other institutions comes from her exclusive relationship with Kovesi. Laura Codruta Kovesi and Florian Coldea are officers of a foreign secret service of a partner country of Romania. That's why Florian Coldea forces RIS to help Kovesi all the time withplagiarism, with the NACDTCU, with the commissions, with everything, so Kovesi will stay theirfunction". Independently, the President of the Superior Council of Magistracy (LiaSavonea) noticed ex officio only in the case in which her name was put inpublic discussion, associated with a former colleague and principal collaborator at the Court of JusticeBucharest Appeal, Presiding Judge of HCCJ.Thus, by the Section Decision for judges no. 475/14.03.2019 defended the professional reputation, keeping in mindthat the expression "Savonea's man", associated with one of the members of the panel,brings a serious prejudice to impartiality, inducing the idea among public notice that it is notcan guarantee a fair trial and that Judge Daniel Grădinaru hashe abused her position, suggesting her lack of impartiality. Also, from the same register is the connection that the journalist makes aboutJudge Simona Nenita, linking her husband to a convicted personcorruption.

Inexplicably, in a case in which the professional reputation of a prosecutor (Alexandra Carmen Lăncrănjan) could be defended ex officio, it was stated in the Plenum Decision no. 366/27.03.2018 that this "aspect was not requested". The request made by the Chief Prosecutor of NAD at that time, Laura Codruta Kovesi, aimed at the way in which the press reflected the information made public by press release no. 1056/V111/3 of 13.11 .2017 of the National Anticorruption Directorate, stating that "this type of media attack, targeting the judicial officers, and in connection with a criminal investigation of the ongoing Anticorruption Directorate, which deals with the investigation of criminal offenses, is a form of interference in the work of prosecutors and are likely to affect the independence of the judiciary system."

Statements of the type "Without prosecutors and judges dedicated and attached to binom ${ }^{17}$ fake specimens cannot be delivered and acceptedand given outside sentences courtrooms. Their judges are placed in full scholarly distributed, andprosecutors have a field covered by the umbrella of secret protocols concluded with the RIS. Judges who are attached to occult binom smell from a post office. Some come from prosecutors initially trained as militiamen. Their tracksprofessional is quickly directed not through contests, but by side decisions. There are already famous black marks from the HCCJ, but also from the courts of appeal. Only letdoubtful of the solutions given by Ioan Bogdan, Ionuţ Matei, Şelaru, Popa. CamelliaBogdan is already a classic case, even revealed by Coldea and Kovesi in front of himBasescu. In the RSCM system, judges Mateescu, Chiş, Ghena, and the Prosecutors Section is fully registered."The Squirrel" fromNAD stands in turn to drop Kovesi, and "waves at her with files to get her up. We understand ofwhat the battle for verifying the ones covered by justice is a sort of Stalingrad."considered journalistic exaggerations based on the existence of earlier press issues. By referring to "certain prosecutors", it is considered not to conclude that the journalistic approach is likely to induce the idea that the wholethe judiciary system would be biased and loyal to certain obscure interests (Plenary Sessionno.604/05.24.2018; Decision of the Plenum no. 605/24.05.2018).

Dismissing some judicial officers who participated in the protests on the stairs of the Bucharest Court of Appeal ${ }^{18}$ ("I have written here about other protests of the judicial

\footnotetext{
${ }^{17}$ Colloquial term which, for a certain part of the press in Romania, designates the collaboration between the Romanian Intelligence Service (RIS) and the National Anticorruption Directorate (NAD).

${ }^{18} \mathrm{See}$ web page https://www.hotnews.ro/stiri-esential-22704717-video-protest-magistra-ilor-treptele-curapel.htm[last consulted on 08.02.2020].
} 
officers, wondering each and every time how large the number of those who agreed toserve the "system" instead of serving citizens' rights.Now, however, seeing that many young judicial officers have lined up behind Danileţ and Bogdan, I have some fear about the future of this country. If the RSCM does not intervene now to penalize those who have made this instigation amongst young judicial officers, we will not be able to assist the restoration of the whole "System" that has functioned over the past two decades as a political weapon, in front of which the citizen was entitled only to status of sure victim. And it is not known whether, when the "System" recovers all of its lost territories now, there will be one like Tudorel Toader to defeat it by putting up the science of books against those who abandon the power of the law in favor of the servileness that yields ephemeral advantages "seems insignificant, by the decision of the Plenum no.1030/01.11.2018 disposing of the defense of the professional reputation and the defense of the independence of the judiciary.

It was necessary for a request filed by 172 judicial officers for defenseof the professional reputation by the Plenum's Decision no.51/14.03.2019, in relation to the six months ago of the lawyer Aurelian Pavelescu at the Romanian judicial officers present at the protest organized on 16.09.2018 at the Court of Appeal Bucharest, as they were named "impostors", "thugs", "imbeciles", "they are the mafia state", "the political police of Romania", "the most corruptof all Romanians","Bolsheviks", "corrupt judicial officers", "loafers", "ax tails", "hooligans", "politically used animals", "bandits".The RSCM Plenum noted that the limits of the freedom of expression had been exceeded and the public opinion was induced that the participating judicial officers did not have a good moral and professional reputation,professionalism and do not adequately fulfill their attributions. There is a serious prejudice to the image of the justice in Romania.

Also, although the Plenum Decision no. 1138/31.10.2017 found that the independence, prestige and credibility of the judiciary system was impaired, although it could have an active role, the RSCM did not send a point of view to the Constitutional Court in the legal conflict of a constitutional nature concerned the issues in question. The RSCM Plenum noted that "the only acts drawn up by the Romanian Intelligence Service officers were information notes that have a classified regime and are found in the file only if the case prosecutor has requested their declassification or some phone note reproduction notes constitute criminal prosecution only with respect to article 143 of the Criminal Procedure Code, respectively, if a report of the judicial police officer designated by the case prosecutor or the latter is drawn up.False information has therefore been presented that has led to the undermining of the independence of the judiciary and the weakening of public confidence in judicial officers, as a result of which their independence may be impaired and can put pressure on the work of prosecutors, affecting both their own image and the institution".

The division of careers, which underpinned the division of the Plenum competences between the RSCMsections, has already given rise to contradictory decisions. For example, by the Prosecutors Section Decision no. 699/13.11.2018 dismissed the request for defense of professional reputation formulated by Gheorghe Stan (prosecutor, deputy chief inspector of the Judicial Inspection) on an article in which a press release issued by the Prosecutors' Association of Romania-Braşov Branch ("extending the mandate of the Judicial Inspectorate by issuing an emergency ordinance, was appreciated by the majority of the judicial officers as a particularly dangerous measure because, in this way, the political power came to call directly directing the Judicial Inspection, a situation that is not in line with the principles of the rule of law"). The Prosecutors' Section considered that the press article refers to views on GEO no. 77/2018, not seeing concrete aspects of the petitioner's activity.

The competence to investigate the legality of administrative acts belongs to theadministrative litigation and only incidentally may be investigated by the courtwho is prosecuted in the 
matter in which an allegation is brought incriminal matters regarding the acts/deeds committed in connection with the issuance of the actrespectively.The Plenum of the Superior Council of Magistracy also noted that, throughanswers given to reporters, Tudorel Toader, the minister of justice, has strictly referredon how to challenge theawfulness of government decisions, and not onoffenses and persons identified in the press release of theNational Anticorruption Directorate of September 22, 2017. Also, apresented in principle, the way and the powers to establish legalityan act issued by the government, as well as the categories of normative acts that can be submittedsuch control. Although the Superior Council of Magistracy has concluded a Collaboration Protocolwith the National Audiovisual Council on November 17, 2011, it isinoperative, the RSCM never revealing the public institution with attributions inaudiovisual in the period 2017-2019, although this was constantly achieved induring the term of the former RSCM mandate (according to article4, "NAC may refer to the RSCM regarding the presentation in the audiovisual programs of opnions expressed by judicial officers withon ongoing trials or on cases with which it washe noticed the prosecutor's office.(2) NAC verifies the RSCM notifications on possible cases ofnonobservance by the radio or television stations of the provisions of Law no.504/2002, as subsequently amended and supplemented, the provisions of Articles 38, 42, 43 and 44 or any other relevant provisions of Decision no. 220/2011 on the Coderegulation of audiovisual content.(3)NAC checks the RSCM notifications onthe provision of the unrealistic data referred to in Article 5 by radio or television stations and, where it decides they are well founded, exercise legal powers to ensure that correct and complete information is transmitted to the public by exercising the right of rectification when it comes to obvious and significant errors, or the right to reply."

\section{Conclusion}

According to the opinionof the Bureau of the Consultative Council of European Judges, made public on the $25^{\text {th }}$ ofApril 2019, issued at the request of the Romanian Judges' Forum Association, regarding the situation of the judiciary system's independence in Romania, judges in Romania and beyond have the legitimate right to protest against any policies or actions that affect their independence in an enviroment based on mutual respect and in a manner that meets the need to maintain the independence and impartiality of justice. The independenceof the judiciary is essential for upholding the rule of law principle and for thesystemto properlyfunction. This independence must be actively enforced and attacks onjudicial institutions, judges and prosecutors can have negative effects if there are no effective measures in placeto prevent certain individuals (especially from the political spectrum) from criticizing court rulings, undermining the judicial officers' credibility or exerting pressure on them. In Romania, there is significant mass media pressure exerted on the judiciary (see the attached table), raising legitimate doubts about the effectiveness of the supervisory work carried out by the National Audiovisual Council. Since 2013, the Commission's Report to the European Parliament and the Council on the progress made by Romania under the Mechanism ofcooperation and verification, made public on the $30^{\text {th }}$ of January 2013, has recommended "the introduction of a clear framework on the prohibition to criticize court rulingsand to undermine the activity of the judicial officersor to put pressure on them andto the effective application of these requirements, revising standardsto ensure the existence of free andpluralist media, while ensuring effective remedies against the violationof fundamental human rights and the exercise of unjustified pressures and the use of intimidation by the mass media onthe judiciary system and the institutions involved in combating corruption. Measures should be taken to ensure that the National Audiovisual Council is truly independentand it should fully fulfill its role by establishing and applying acode of conduct in this regard."

Besides the usefulness of information campaigns in the press, in order to know and avoid, as much as possible, the forms of obstruction of justice (for example, baseless accusations or 
slander and libel), the Romanian society needs mainly institutions that respect the minimal conduct of the rule of law, effective and stable. Unfortunately, the Romanian Superior Council of Magistracy has demonstrated neitherstability nor aproactive role in the defence ofjudicial officersagainst acts meant to affect independence, impartiality or professional reputation $^{19}$, between January 2017-April 2019, with the exception of one situation, in which some of the victims were members of the Superior Council of Magistracy, especially the currently elected president. Despite the fact thatjudicial officers are slandered and dragged through the mud daily during numerous broadcasts of various television stations, on websites and printed press, the reactions of the Superior Council of Magistracy are almost non-existent, although their role is also to communicatepublicly when false information is presented. Moreover, the RSCMcommunicates publicly, in almost every situation, by at least four to five distinct voices(The RSCM Plenum, the sections, the RSCMpresident and members of the civil society, etc.), the latter issuing personal and extraordinary press releases, as if the institution were individual and not a collective body. ${ }^{20}$

Although almost all of the elected members of the current RSCM have declared, through their applications, that they are determined to have an active and ferm role in defending judicial officers against acts that could potentially affect their independence, impartiality or professional reputation, this commitment seems to have just been a part of their election campaign. The RSCM has not taken any further steps to provide adequate support to criticized judicial officers that undermine the independence of the judiciary system(for example, financial or legal aid to judicial officers seeking moral damages through actions brought before courts). The press releases issued in very rare cases between January 2017 and April 2019 are not covered by the press in a way equivalent to one in which the initial criticisms were broadcast and, as is apparent from the resolutions published by the RSCM in the field, the National Audiovisual Council was not even noticed once for rectifying the information by channel distributing responsible for the slander. Undoubtedly, in order to fulfill the constitutional obligation to guarantee the independence of justice, the Superior Council of Magistracy must defend the body of judicial officers against acts that affect the independence, impartiality or professional reputation of judges and prosecutors. In order to achieve this goal, given the context illustrated supra, it is imperative to regulate extremely short deadlines for the ex officio referral, to solve these requests/complaints, to properly facilitate the defenceof independence, impartiality or professional reputation, but also for disseminationof the resolutions provided by the Superior Council of Magistracy in the press, especially the channel that had broadcasted the slandering remarks, legally enstating the "right to reply and defend" in such cases. Also, by modifying the legislative framework, the RSCM could be tasked tofile claims directly to the courts in order to defend the public image ofjudicial officers for whom the requests mentioned previously had been admitted or at least to support, from the RSCM budget, the expenses necessary for filing such claims. ${ }^{21}$ Last but not least, in

\footnotetext{
19 The SCM did not request the support of the Consultative Council of European Judges or the Consultative Council of European Prosecutors, for example. It could also have an active role in the European Network of Judicial Councils in relation to the situation of the independence of the judiciary system in Romania. The CCJE condemned the "repeated and unprecedented attacks of political actors against Romanian judges" only after the Romanian Judges' Forum Association's intimation, having the lack of involvement of SCM.

${ }^{20} \mathrm{See}$, most recently, the press release entitled "History lessons are Truth", available at https://www.csm1909.ro/323/Comunicate-societatea-civil\%C4\%83-CSM[last seen on 08.02.2020]. Some of the statements, belonging to a member of the SCM, create the impression of serious imbalances in the magistracy, which could minimize the very constitutional role of the Superior Council of Magistracy. Surprisingly, they are allowed by other members without proper public explanation.

${ }^{21}$ In France, under a 1958 law, the Ministry of Justice pays lawyers' costs in order to allow the judicial officers concerned to bring an action in court. The judges who have been attacked personally hesitate most often to
} 
order to faithfully reflect the analysis of requests for the defence of independence, impartiality or professional reputation by each member of the RSCM, the Regulation on the organization and functioning of the Superior Council of Magistracy should also allow fordissentingopinions on all resolutionsmade with a majority of votes, based on article 30 of Law no.317/2004 regarding the Superior Council of Magistracy. Law 317 is then changed provcision where a member could undergo for a second time. ${ }^{22}$

\section{A. Journal}

\section{Bibliography}

Arato, Andrew. "Unconstitutional Constitutional Amendments: Constitutional Courts as Guardians of the Constitution?" Constellations 18, no. 3 (September 2011): 324-51. https://doi.org/10.1111/j.1467-8675.2011.00641.x.

Creciun, Natalia. "Particular Forms of Evaluation and Assessment of Judges: Between Exigency of a Consolidated Justice and Violation of Justice Independence." Revista $\begin{array}{llllll}\text { Institutului } & \text { National } & \text { Al } & \text { Justitiei } & 49 & \text { (2019). }\end{array}$ https://heinonline.org/HOL/Page?handle=hein.journals/rvisnjut49\&id=55\&div=\&collecti on $=$.

Holvast, Nina L., and Nienke Doornbos. "Exit, Voice, and Loyalty within the Judiciary: Judges' Response to New Managerialism in the Netherlands." Utrecht Law Review 11 (2015).

https://heinonline.org/HOL/Page?handle=hein.journals/utrecht11\&id=147\&div=\&collect ion $=$.

Keller, Helen, and Severin Meier. "Symposium on Jeffrey 1. Dunoff and Mark a. Pollack, 'the Judicial Trilemma' Independence and Impartiality in the Judicial Trilemma." In AJIL Unbound, 111:344-48. Cambridge University Press, 2017. https://doi.org/10.1017/aju.2017.85.

Mikuli, Piotr. "In Search of the Optimal Court Administration Model for New Democracies." In Judicial Power in a Globalized World, 281-89. Springer International Publishing, 2019. https://doi.org/10.1007/978-3-030-20744-1_18.

Nicolae, Pavel. "SELECTIVE ASPECTS ON THE EVOLUTION OF THE REGULATIONS REGARDING THE JUDICIARY IN THE ROMANIAN CONSTITUTIONS AND IN THE ROMANIAN LAW 100 YEARS AFTER THE GREAT UNION." Revue Européenne Du Droit Social, no. 04 (41) (2018): 22-38.

Schwartz, Alex, and Melanie Janelle Murchison. "Judicial Impartiality and Independence in Divided Societies: An Empirical Analysis of the Constitutional Court of BosniaHerzegovina." Law \& Society Review 50, no. 4 (December 1, 2016): 821-55. https://doi.org/10.1111/lasr.12237.

Selejan-Guțan, Bianca. "Romania: Perils of a 'Perfect Euro-Model' of Judicial Council." German Law Journal 19, no. 7 (December 1, 2018): 1707-40. https://doi.org/10.1017/s207183220002321x.

Straumann, Benjamin. "Roman Ideas on the Loose." Critical Analysis of Law 4, no. 2 (November 30, 2017). https://cal.library.utoronto.ca/index.php/cal/article/view/28856.

Viorescu, Razvan. "CONFLICTS OF A CONSTITUTIONAL NATURE BETWEEN THE GOVERNMENT OF ROMANIA AND THE JUDICIAL AUTHORITY - THE SUPERIOR COUNCIL OF MAGISTRACY." European Journal of Law and Public Administration 3, no. 2 (2016): 5-17.

defend themselves, especially in cases involving a pending file, and maintain independence and demonstrate that they will remain impartial.

${ }^{22}$ Thorsten Geissler and Corina Rebegea, "The old and New Romanian Superior Council of Magistracy", Konrad Adennauer Stiftung, 2011, pg. 3. 
